Местото на Рина Усикова во славистиката и македонистика

D. Pandev (Skopje, Macedonia)

\title{
Rina Usikova's Contribution to the Study of Sl. and Mac. Literatures
}

За Усикова сум имал можност да зборувам и пред неа, на научен собир во Москва по повод македонско-руските врски од 1945-1991 година. Убав е тој обичај да се зборува пофално во присуство на личноста. Тоа некогаш неизбежно носи две омилени јазични форми на Усикова - здравицата и поздравите. Но животот не е секогаш во здравиците, и не е секогаш во поздравите, во оние поздрави што продолжуваат. Бидејќи постои една форма наречена - последен поздрав. Но, на последните поздрави обично се навраќаме на почетоците.

Па јас сакам во една-две реченици, ако е тоа можно, да го истакнам местото на Рина Усикова во славистиката воопшто, и особено во руската македонистика.

Рина Усикова започнува онаму кајшто подзапира Бернштејн, а тоа е морфонологијата, иако тие обично го нарекуваат тоа, барем Рина Усикова, со зборот морфологија, во нејзината прва кандидатска работа што е објавена во Скопје 1967 година и којашто меѓу другото е резултат на исцрпно познавање на македонскиот јазик, македонската дијалектологија и македонската литература.

Сакам да истакнам, меѓу лингвистите-македонисти, Рина Усикова беше најдобар познавач на македонската литература во нејзино време и во онаа смисла што таа се покажа и како врвен преведувач, па дури и како одличен познавач на литературните дела. Таа е познавач и на македонската дијалектологија, во онаа смисла што имала можност да ги преслуша сите ленти во Академијата на Науките на СССР, имено на магнетофонските записи од Егејска Македонија, исто како што имала можност низ Македонија да се вслушува во разговорната реч и во јазичните ситуации, па го заокружува своето творештво надоврзувајќи се на јазичната теорија на Никита Илич Толстој за јазичната стратификација на јазикот.

Го нагласува таа тоа и во своите трудови, дека токму се надоврзува на проучувањата на Бернштајн, го укажува тоа токму на она место кајшто Бернштејн всушност на извесен начин се соочил со македонската ситуација, можеби не познавајќи го толку добро македонскиот јазик, а тоа се проблемите со глаголските групи. Се надоврзува на Никита Илич Толстој токму на онаа тема којашто денес е престижна во руската лингвистика, особено во когнитивната лингвистика и во лингвокултурологијата. И сакам овдека всушност да истакнам дека овие теми не 
се само на Бернштејн и не се само на Толстој, но Рина Усикова сакала да ја нагласи и да ја истакне македонската нишка во руската славистика, имено дека таа врска е поврзана со две големи и значајни имиња, од една страна со Бернштејн, којшто е основач на современата руска славистика, на словенската филологија на МГУ по 1945 година, и од друга страна со Никита Илич којшто ќе се издигне во еден од врвните културолози во руската славистика, нешто што денес е престижно во лингвистиката.

Интересирајќи се пошироко за странските македонисти, и познавајќи се речиси со сите нив, си го поставив еднаш прашањето: Кој всушност од странските македонисти ужива највисок респект во својата академска средина? Разбирливо, да се даде одговор на едно вакво прашање не е лесно, зашто од една страна тоа може да се направи чисто во самата академска средина, а од друга страна да се провери и во литературата. Па читајќ́ ја руската лингвистика, и општата лингвистика на руски јазик, во една престижна книга од Хроленко и Бондалетов, врвни лингвисти во современата руска лингвистика, т.е. историчари на лингвистиката, во одделот на социјалната лингвистика, наидов на едно место во кое што се вели дека вниманието на странските и руските социолингвисти во последните години го привлекувале четири теми: варијантите на јазиците, јазичните ситуации, меѓународните јазици, и литературните јазици. Во оваа потточка, во оваа книга за општа лингвистика, пишува дека од словенските литературни јазици како најмлад се јавува македонскиот литературен јазик појавен во 1945 година и дека тој е особен предмет на проучување на Рина Павловна Усикова. Името на Рина Павловна Усикова во овој контекст е спомнато со името на врвните социолингвисти на денешното време. Во таа смисла сакам накусо да се задржам на клучните лингвистички теми на коишто им обраќа внимание Рина Усикова во рамките на своите научни проучувања од 1965 година кога дошла прв пат во Македонија а таа долго ни ја раскажуваше нејзината прва средба со Блаже Конески, бидејќи восхитена од таа средба, недоволно познавајќи го македонскиот јазик на сите им велела: Имав среќa со Блаже Конески! Всушност таа само направила некоја фонетска промена во којашто зборот «среќа» го поставила меѓу зборовите срешта, встреча, средба, и вистинската среќа. Но сите оние кои имале среќа да соработуваат со Конески, навистина успеале во лингвистиката. Оттаму, сакам да истакнам дека Рина Усикова во своето лингвистичко дело особено ја нагласува, прво, македонската парадигма на јазичната самосвест. Станува збор за едно прашање од историјата на литературните јазици и Усикова ова прашање го разгледува на долг протег од VI век па сѐ до денес, особено место посветувајќи му на XIX век и во тој контекст на Прличев.

Сакам да ја истакнам стилистиката и особено нејзиниот прилог во разработката на функционалноте стилови во кои што таа дава несебичен придонес во една од најтешките теми во функционалната стилистика, а тоа е разговорниот стил, разгледувајќи го на сите рамништа, од најниско до највисоко и обратно, или поинаку кажано од оздола до најозгора и од озгора до најоддолу, отворајќи некои клучни теми кои особено доаѓаат во теоријата на социјалната стратификација на јазикот. Рина Усикова, особено на оваа тема се задржува на темата за јазичниот супстандард, тема на којашто ѝ посветила особено внимание. И овдека сакам да истакнам еден личен момент кога го употребив овој збор, супстандард, во наслов на еден свој реферат, Рина Усикова ме прекори: «Кај си го нашол тој збор? Нема такво нешто!» Јас ѝ кажав: «Тоа го има кај вас», но како што кажа колешката 
Црвенковска, едноставно сакаше да ме провери, исто како што во основа ја отвора онаа тема за идиолектот, и особено во разговорниот стил, тема што сѐ уште чека свои проучувачи.

Сакам да се навратам и на нејзините први проучувања во областа на морфологијата и да ги спојам со нејзините заокружени проучувања во областа на јазичната стратификација. Рина Усикова отвора една клучна тема, а тоа е идио-етничниот слој на јазичното значење, и таа вели, парафразирам, идиоетничкиот слој на јазичното значење може да има примарна улога при употребата на формата. Се разбира, овде сета формална граматика паѓa во вода и доаѓаат до израз новите современи пристапи во граматиката во коишто јазикот се поврзува со етникумот, со народот, со нацијата. Сакам овдека да истакнам дека токму во една статија што Усикова ја изложи на Филолошкиот факултет, за да ја докаже оваа теза таа ја завршува статијата со пример за употреба на имперфектот во научниот стил и особено го дава концептот «езеро». А со овие прашања Усикова ни остава отворени теми на коишто треба да се надоврземе, а една од тие отворени теми секако е за секундарната функција на транспозицијата: како може имперфектот да се замени со перфектот, што во основа е наша, македонистичка, тема на којашто треба да размислуваме, исто како што треба пошироко да опфатиме некои концепти кои се, исто така, чисто македонистички, а на коишто Рина Усикова вдахновено им дала простор, како што е концептот «езеро». К'е ви цитирам само еден пример од разговорниот стил: «На езерото знае да има големи бранови». Овдека всушност Усикова инсистира на модалноста на глаголот «знае» којшто ја има оваа употреба не само кај македонските говорители колку што ја има кај они што го чувствуваат концептот бран и концептот езеро. Јас неслучајно го заокружувам своето искажување токму за овој концепт - езеро, бидејќи кога своевремено се зафатив со проучување на поезијата на Блаже Конески, ме интересираа, и не само мене, туку многумина, во таа 1974 година, кога не ја познавав Рина, кои се «трите крупни жени» од омилената песна на Конески. Колку и да добивав одговор, во еден од сите тие одговори редовни беше вклучена Рина, а оваа песна завршува со онаа «невидлива мрежа» што Конески ја воспоставува врз трите македонистки, една од Босна, најверојатно, едната од Белград, кои најверојатно биле на гости кај него. Но можеби сето тоа се случувало и на брегот на Охридското езеро, бидејќи концептот езеро сепак заслужува внимание, а Рина ни дава таков простор.

Сакам на извесен начин да ги заокружам моите спомени за Рина со првата и последната средба. Нашата прва средба беше во Хотел Палас, тоа беше закажана средба иако претходно повеќепати се договаравме кој ден ќе биде таа средба. Можам да истакнам дека тоа е една од најдолгите, но воедно и најбрзотрајните средби во Хотел Палас. Тој ден Рина толку убаво ми ја објасни Москва, што веќе утредента можев да кажам дека сум Московјанин. Од друга страна, сакам да истакнам дека една од нашите последни средби, и тоа сепак се оние моменти, што остануваат во трајно сеќавање, е отворањето на Куќата на Уранија, како дом на Македонската академија на науките и уметностите. Рина сакаше да оди, но не знаеше како. Се разбира, јас тоа го изведов на некој неверојатен начин, поминувајќи ги сите препреки коишто не пуштаа ниедна кола да стигне до домот на Уранија, куќата на Уранија и она што го знам само јас и Рина и уште неколкумина, а сега го споделувам со Вас: првата личност што се качи во лифтот во Куќата Уранија беше токму Рина Усикова, а јас ја придружував. Но во лифтот е токму онаа тео- 
рија за стратификација, за вистинска стратификација кога од езерското поднебје се издигнуваме на оние повисоки сфери во науката.

Нека ѝ е вечна слава и да ја спомнуваме во сите наши понатамошни разговори од областа на македонистиката и славистиката зашто од Рина многу научивме, а тоа можеме сега понатаму да го продолжиме во нашите статии. Вечна ѝ слава!

Сведения об авторе:

Димитар Пандев,

доктор филологии

профессор

Университет им. Свв. Кирилла и Мефодия в Скопье (Македония)
Dimitar Pandev,

$\mathrm{PhD}$

Professor

University Sts. Cyril and Methodius University in Skopje (Macedonia) 